\title{
Influence of post-harvesting residual stand structure on canopy light transmittance in Ontario's boreal mixedwood forests
}

\author{
by William C. Parker ${ }^{1 *}$ and Mahadev Sharma ${ }^{1}$
}

\begin{abstract}
A lack of local and regional markets for trembling aspen (Populus tremuloides Michx.) and white birch (Betula papyrifera Marsh.) can result in large numbers of merchantable-size hardwood stems with little commercial value, which complicates even-aged management of Ontario's boreal mixedwood forests. To help identify potential management approaches to address this periodic economic situation, the relationship of stand structure with canopy transmittance was examined in recently harvested boreal mixedwood stands with differing hardwood tree retention levels. Canopy transmittance and residual stand structural features were measured in $483,0.612$ ha circular plots established in recently harvested stands in 12 locations across northern Ontario. For both trembling aspen- and white birch-dominated residual stands, canopy transmittance exhibited a negative exponential relationship with basal area, density, and stand density index. Nonlinear mixed effects models sometimes differed significantly between these two residual stand classes, likely due to species differences in crown architecture and stem size. Application of these models to guide silvicultural activities and improve regeneration planning and biodiversity conservation to better meet local management objectives is discussed.
\end{abstract}

Keywords: boreal mixedwoods, canopy retention, canopy transmittance, regeneration, stand structure, trembling aspen, understory light, white birch

\section{RÉSUMÉ IN TRANSLATION}

Labsence de marché local pour le tremble (Populus tremuloides Michx.) et le bouleau blanc (Betula papyrifera Marsh.) peut se traduire par une abondance de tiges marchandes de faible valeur commerciale sur les parterres de coupe, ce qui vient compliquer l'aménagement équienne des forêts mixtes boréales de l'Ontario. On a tenté de trouver des avenues d’aménagement permettant de saccommoder de cette situation économique périodique en étudiant la relation entre la structure du peuplement et la transmission de la lumière dans des peuplements nouvellement coupés en forêt boréale mixte avec divers niveaux de rétention de feuillus. On a mesuré la transmittance du couvert et les caractéristiques structurelles du peuplement résiduel dans 483 placettes circulaires de 0,612 ha établies dans des peuplements ayant fait lobjet d'une coupe récente à 12 endroits dans le Nord de l'Ontario. Dans les peuplements à dominance de tremble, tout comme dans ceux à dominance de bouleau blanc, la transmittance du couvert montre une corrélation exponentielle négative avec la surface terrière, la densité ainsi que l'indice de densité de peuplement. Les modèles de régression linéaire mixtes différaient parfois de façon significative entre ces deux classes de peuplements résiduels en raison, sans doute, des différences dans larchitecture de cime et dans la taille des tiges pour chaque essence. Nous abordons enfin l'utilisation de ces modèles pour orienter les travaux sylvicoles et pour mieux planifier la régénération ainsi que la préservation de la biodiversité afin de mieux répondre aux objectifs locaux d’aménagement.

Mots-clés : forêts mixtes boréales, rétention du couvert, transmittance du couvert, régénération, structure de peuplement, tremble, lumière en sous-étage, bouleau blanc.

\footnotetext{
${ }^{1}$ Ontario Forest Research Institute, Ontario Ministry of Natural Resources and Forestry, 1235 Queen St. E., Sault Ste. Marie, ON, Canada P6A 2E5 (bill.parker@ontario.ca, mahadev.sharma@ontario.ca)

*correspondence: William Parker: bill.parker@ontario.ca
} 


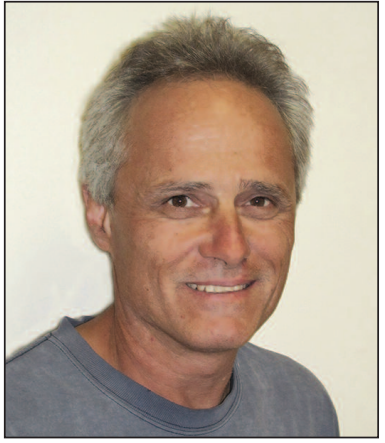

William C. Parker

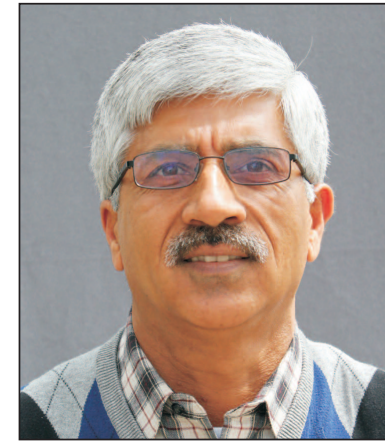

Mahadev Sharma

\section{Introduction}

Mixedwoods are a diverse, productive forest type found across a vast area of the southern boreal forest region of Canada (Rowe 1972; Chen and Popadiuk 2003). Boreal mixedwoods typically occur on comparatively well-drained, nutrient rich, upland sites with deep, medium- to fine-textured soils (Pierpoint 1981; MacDonald 1995). In Ontario, boreal mixedwoods are composed primarily of trembling aspen (Populus tremuloides (Michx.), white birch (Betula papyrifera Marsh.), white spruce (Picea glauca (Moench) Voss), black spruce (Picea mariana (Mill) B.S.P.), and balsam fir (Abies balsamea L.) (MacDonald 1995). Of the two primary hardwood species, trembling aspen is more common on comparatively mesic sites with deep, fine-textured soils, while white birch is more prominent on coarse-textured or very shallow soils over bedrock (MacLean 1960; Rowe 1972). At a landscape scale, boreal mixedwoods occur as mosaics of pure and mixed, single- and multi-cohort stands of varying age (Chen and Popadiuk 2003). The composition, structure, and age of these stands depend on the timing, severity, and size of disturbances and relatively subtle differences in biotic and abiotic site features (Chen and Popadiuk 2003). In Ontario, boreal mixedwoods currently occupy about 5.1 million ha (Watkins 2011), but are potentially adapted to the climate, soil, and site characteristics of 50 to $70 \%$ of the boreal forest region (OMNR 2003).

Public-owned or Crown forests in Ontario are sustainably managed using an ecosystem approach that is based on the assumption that long-term productivity, the provision of ecological goods and services, ecosystem function, and resilience are best achieved using silvicultural practices to create residual stand features and landscape patterns that emulate natural disturbance. The premise is that these patterns are likely to provide the habitat, or niche space, to which forest-dwelling organisms and the ecological functions they perform are adapted (Hunter 1999). Fundamental to ecosystem management at stand scale is the deliberate, permanent retention of uncut patches and scattered living and dead canopy trees of differing species, sizes, density, and spatial configuration to favour the persistence and dispersal of existing species by enriching structural complexity and enhancing stand connectivity (Franklin et al. 1997). In Ontario, implementation of ecosystem management is directed by a series of manuals and guides that provide mandatory direction and suggested practices that have a reasonable likelihood of success in meeting local forest management objectives to create a desired stand composition and structure on a given site (OMNR 2010; OMNRF 2015). Current guidelines for conserving forest biodiversity in Ontario's forests rely on a coarse filter approach to create a variety of ecosystem conditions and habitat suitable for most forest dwelling plants and animals (OMNR 2010). At stand scale, this is achieved during forest harvesting through permanent retention of a combination of well-distributed remnant forest patches and individual living, dead, and dying trees. The level of retention determines the primary silviculture system best suited to attain some desired future forest condition (OMNRF 2015). In forests managed using the clearcut system, standards for conserving biodiversity require remnant forest patches to be at least 0.1 ha and occupy $\geq 5 \%$ of the total area in a clearcut. For individual trees, a minimum of 25 stems $\mathrm{ha}^{-1}$ that are at least $10-\mathrm{cm}$ diameter at $1.3 \mathrm{~m}$ $(\mathrm{DBH})$ and $3 \mathrm{~m}$ in height must be retained.

Although failure to harvest tree stems of merchantable size is considered a wasteful practice (OMNR 2007) that may threaten silvicultural objectives (OMNRF 2015), higher than minimum required levels of retention may be desired to meet specific management objectives, provided the silvicultural system applied is identified as having a high probability of success in attaining a desired future forest condition (OMNRF 2015). Ontario's silviculture guides identify three primary silviculture systems for use in Crown forests: clearcut, shelterwood, and selection. These traditional systems are modified to ensure post-harvesting stand composition and structure better mimics what would remain following natural disturbance. These three systems are further defined by timing and intensity of tree removal, and the effects of tree retention on growing conditions for regeneration (OMNRF 2015). Specifically, the clearcut, shelterwood, and selection silviculture systems are characterized by a residual canopy that creates understory light levels of $>70 \%$, between 30 and $70 \%$, and $<30 \%$, respectively.

Clearcutting is the predominant silvicultural system used in management of boreal mixedwood forests in Ontario and elsewhere, with partial or complete overstory retention used in riparian areas or other areas of concern (Chen and Popadiuk 2003; OMNRF unpublished data). Where markets for both hardwood and conifer species exist, management of boreal mixedwoods supports the production of a variety of primary and secondary forest products and the economies of many northern forest communities (MacDonald 1995). Despite technological advancements in wood processing and increasing global demand for trembling aspen (Balatinecz et al. 2014) and white birch (Duchesne and Rancourt 2005) fibre in recent decades, management of boreal mixedwoods in Ontario and other regions of North America is periodically challenged by poor regional markets for these two species. This economic condition can result in increased retention of lower value stems and species, which complicates subsequent regeneration and management (OMNRF 2015). Beginning in early 2008, the global economic downturn and collapse of the housing and wood product markets (Taylor 2009) initiated a dramatic reduction in demand for boreal hardwood fibre, with the average annual volume of aspen and birch harvested in Ontario from 2008 to 2015 52\% lower than for 2000 to 2007 (OMNRF unpublished data). During this time, manage- 
ment of boreal mixedwoods in many areas of Ontario centred on harvesting of commercially valuable conifer species and veneer-size hardwoods, with delayed harvesting of the remaining merchantable aspen and birch stems. In hardwood-dominated boreal mixedwoods, this approach sometimes created residual stands with $>300$ stems ha $^{-1}$, increasing interest in how retention levels influence understory light conditions in relation to selection of an appropriate silviculture system and regeneration activities. Unfortunately, the relationship between residual stand structure and understory light has not yet been established for Ontario's boreal mixedwood forests.

This recent occurrence of market-driven increases in hardwood tree retention provided an opportunity to model the relationship of canopy transmittance with residual stand structure for the boreal mixedwood forests of northern Ontario. These models can be used to identify the range in residual tree density over which acceptable understory light levels occur for a given silviculture system or, alternatively, the maximum allowable retention level for a given system. Such models can also improve understanding of how tree retention to conserve biodiversity may affect forest management and regeneration planning when harvesting hardwoods is not commercially viable. As well, this information can assist the testing and use of alternatives to clearcutting for managing boreal mixedwoods to better emulate natural disturbance patterns (Bergeron and Harvey 1997; OMNR 2015). The primary objective of this study was to characterize and compare the relationship of average canopy transmittance with stand structural features for both aspen- and birch-dominated residual stands to provide simple models as operational tools to assist boreal mixedwood management. We anticipated a significant negative, nonlinear relationship of canopy transmittance with stand structural features, as reported for many boreal forest types (Lieffers et al. 1999; Comeau et al. 2006; Beaudet et al. 2011). We hypothesized that these relationships would differ between aspen- and birch-dominated residual stands due to inherent functional differences in the canopy architecture of the two species (Beaudet et al. 2011).

\section{Materials and Methods Study sites}

Study sites were located in 26 managed, recently harvested areas ( $\leq 3$ years between harvesting and sampling) and three unmanaged stands at 12 locations in the boreal mixedwood forest of northern Ontario (Fig. 1). The semi-mature and mature stands in the managed forest areas were originally scheduled for clearcut harvesting, with a target of retaining a minimum of 25 trees ha $^{-1}$ to meet biodiversity objectives (OMNR 2010). However, due to depressed aspen and birch markets at the time of harvesting, only marketable conifer stems and veneer quality hardwood were removed. This resulted in residual canopies with a range of basal area and density comprising mostly aspen and birch, with a composition, structure, and spatial distribution dictated primarily by pre-harvesting species composition, the location of valuable stems, and local markets for boreal hardwoods. The spatial pattern of residual trees also varied somewhat with harvesting method and machinery used, i.e., cut-to-length or full-tree logging and skidding to road side.
Plot and individual tree measurements

In each cutover and unmanaged stand (hereafter referred to as blocks), several $(\mathrm{n}=2-59) 14-\mathrm{m}$ circular radius $\left(615.8 \mathrm{~m}^{2}\right.$ area) plots were established along a series of parallel, linear transects, spaced $30 \mathrm{~m}$ apart and at least $50 \mathrm{~m}$ from block borders, with the centre of each sample plot at least $2 \mathrm{~m}$ from the nearest canopy tree to avoid physical interference with photography. In a block, sample plots were separated by at least 30 $\mathrm{m}$ along transects so as not to overlap. The exact distance between plot centres along these transects varied slightly to avoid: (1) stumps, fallen trees, slash piles, and other physical obstacles; and, (2) dense patches of understory woody vegetation that would interfere with canopy transmittance estimates (see below). Sampling intensity in stands was based in part on balancing the need for plot data adequate to estimate canopy transmittance over the full range in residual structure created by this economic condition with time and resources available for field measurements and image analysis.

In each plot, $\mathrm{DBH}$ and species were recorded for all living and dead standing trees with $\mathrm{DBH} \geq 10 \mathrm{~cm}$ and heights $\geq 3$ $\mathrm{m}$. For trees with multiple stems, number and DBH of all living and dead stems above this size threshold were noted. Total height of dominant canopy trees in a block was measured on a subsample of residual trees using a Vertex III ultrasonic distance meter (Haglöf Sweden $A B$, Långse le, Sweden). Plot basal area (BA) was determined from DBH measurements of individual trees, and stand density $(\mathrm{N})$ was estimated from the total number of trees in the circular sample plots, with both variables scaled to a per hectare basis. The percentage of total BA and $\mathrm{N}$ from multiple-stemmed trees was calculated for each plot and species. Stand density index (SDI), an expression of relative stem density that integrates N, BA, and tree size and is independent of stand age and site quality, was calculated using the method of Reineke (1933), where:

$$
\begin{aligned}
& \mathrm{SDI}=\mathrm{N} \times\left(\mathrm{D}_{\mathrm{q}} / 25\right)^{1.6} \\
& \text { and } \mathrm{D}_{\mathrm{q}} \text { is quadratic mean diameter calculated as } \\
& \mathrm{D}_{\mathrm{q}}=((40,000 / \pi) \times(\mathrm{BA} / \mathrm{N}))^{0.5}
\end{aligned}
$$

(West 2009). Approximate age at time of measurement for all plots was based on estimated year of stand (i.e., block) origin from the provincial forest resource inventory.

Our sampling intensity was constrained somewhat by the location and availability of recently harvested stands with the desired residual structure. This precluded rigorous sampling adequate to account for potential ecosite effects on the relationship of canopy transmittance with stand structure. We sampled 455 plots in 26 harvested blocks. Residual stands with $<300$ stems ha-1 were most common, enabling a fairly high sampling intensity within this range of stand density. Because stands with comparatively higher density were less frequent, we sampled an additional 28 plots in three fully stocked, unmanaged, pure aspen stands. Unfortunately, no mature unmanaged birch stands were available to sample.

\section{Hemispherical photographs}

Hemispherical photographs were used to estimate the amount of light transmitted through the overstory canopy to the understory at 1-m above-ground. The overstory canopy in this study is defined as all living and dead trees $>10 \mathrm{~cm}$ 


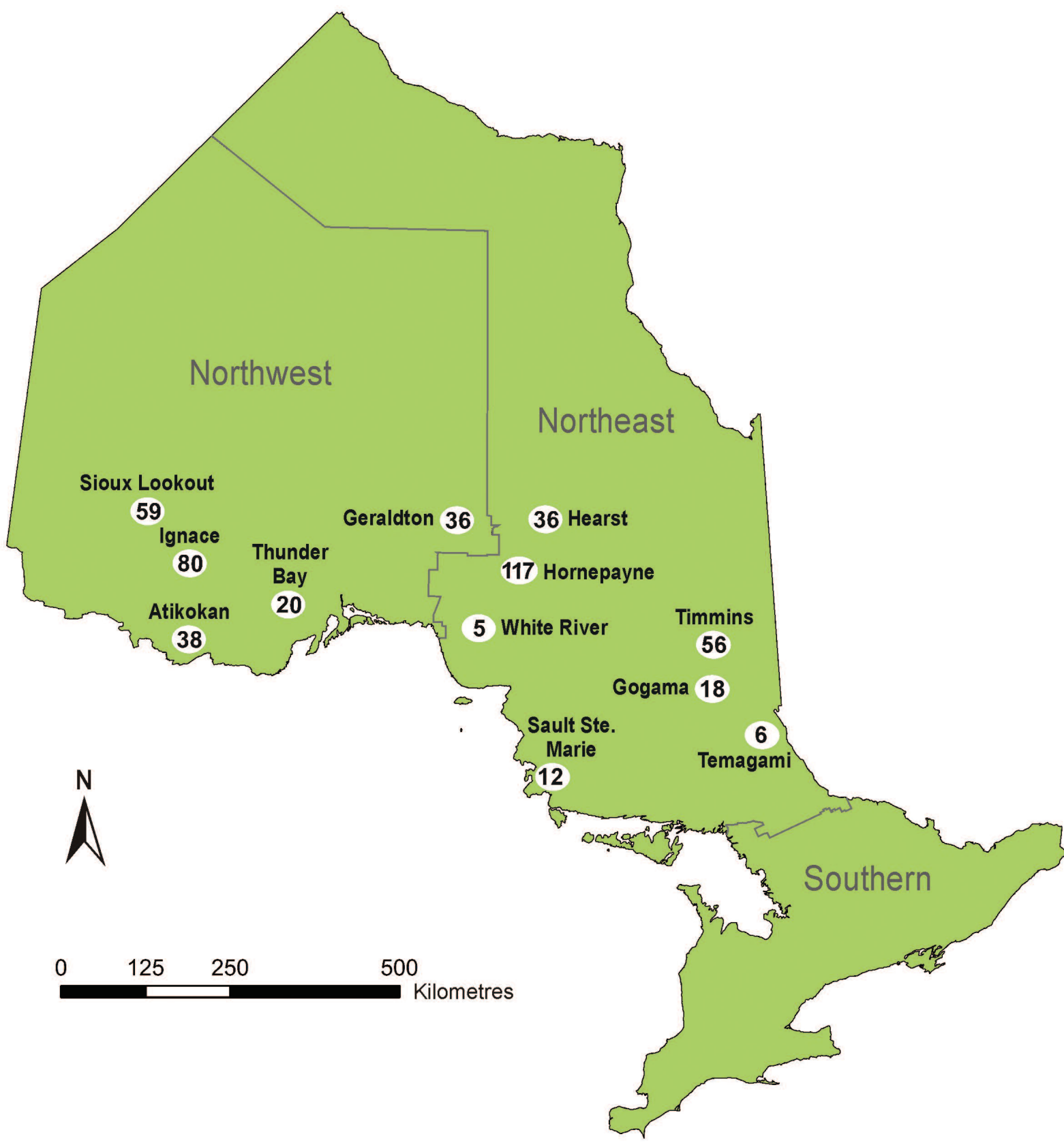

Fig. 1. Location of 12 field sampling sites in the northeast and northwest administrative regions of Ontario. Numbers in white circles indicate the number of sample plots established at a given location.

$\mathrm{DBH}$ and $>3 \mathrm{~m}$ in height, as per provincial policy outlining canopy tree retention (OMNR 2010). Since most managed stands sampled were harvested within three years of measurement, sample plots were typically free of dense, taller understory vegetation. While we attempted to avoid disturbance to sample plots, it was sometimes necessary to manually remove woody vegetation $>1 \mathrm{~m}$ in height and $<10 \mathrm{~cm} \mathrm{DBH}$ in the immediate vicinity of the camera that could obscure the upper canopy image and interfere with canopy transmittance estimates. For the three unmanaged stands, all subordinate understory vegetation $\geq 1 \mathrm{~m}$ in height and $<10 \mathrm{~cm}$ in $\mathrm{DBH}$ was cut prior to taking photographs.
Digital hemispherical photographs were taken at plot centre using a Nikon Coolpix model P1 digital camera (3264 x 2448 pixel resolution) and a Nikon FC-E8 $180^{\circ}$ field of view fish-eye converter. The camera was mounted on a tripod, levelled, and oriented to magnetic north 1-m above ground. To ensure digital images with good contrast between sky and canopy, photographs were taken at the camera selected, automatic exposure setting, and the next exposure above and below this setting. It was not possible to take all photographs under the preferred diffuse sky conditions free of the influence of glare from direct sunlight. In these cases, a sun blocking device was used to minimize the amount of direct sunlight 
that struck the camera lens. The portion of images occupied by the sun blocker was excluded from image analysis.

Digitized photographic images were edited and analyzed using WinSCANOPY 2004a software (Regents Instruments Inc., Sainte-Foy, QC). This software calculates average canopy transmittance to the understory based on the location of canopy elements, the diurnal path of the sun, and seasonal changes in sun angle for a given location and time. Canopy transmittance was estimated with the global site factor (GSF), the mean percentage of total incident photosynthetically active radiation (wavelength $400-700 \mathrm{~nm}$ ) in the understory over the growing season (May-September). A solar constant of $1370 \mathrm{~W} \mathrm{~m}^{-2}$ and the SOC (standard overcast sky) model of sky region brightness, which assumes diffuse radiation is highest at the zenith and decreases towards the horizon (Gendron et al. 2006), was used to calculate total diffuse and direct solar radiation. For the SOC model, the proportions of diffuse and direct radiation are set at 0.15 and 0.51 , respectively. Digitized photographic images were analyzed using a maximum zenith angle of $70^{\circ}$ to remove the image area near the horizon, which eliminates the influence of land surface features and understory vegetation outside the plot on GSF estimates. To remove operator bias from this subjective stage of image analysis (Robison and McCarthy 1999), all images were processed and analyzed by the same individual.

\section{Statistical analysis}

The harvested and unmanaged blocks were dominated by aspen and birch, with lesser amounts of white spruce, black spruce, balsam fir, jack pine (Pinus banksiana Lamb.), balsam poplar (Populus balsamifera L.), white cedar (Thuja occidentalis L.), red maple (Acer rubrum L.), and white elm (Ulmus americana L.). Each sample plot was classified into a generalized post-harvesting stand composition using the living tree BA percentage by species (OMNR 2003), yielding six distinct residual stand types. Pure aspen $(\mathrm{PtP})$ and pure birch $(\mathrm{BwP})$ stands were defined as containing $>80 \% \mathrm{BA}$ in aspen or birch, respectively. Aspen-dominated $(\mathrm{PtD})$ and birch-dominated (BwD) stands contained 50 to $80 \%$ BA of the primary hardwood species, and $\leq 20 \%$ of BA in all conifer species combined. Aspen leading mixtures (PtL) are stands with a combined BA of aspen and birch $\geq$ conifer $\mathrm{BA}$, but with aspen $\mathrm{BA}$ $>$ birch BA. Birch leading mixtures (BwL) are the same but with higher BA of birch. Very small percentages of balsam poplar that occurred in a few study stands were lumped with aspen in deriving stand type. The number of sample plots in the six stand types by provincial administrative region is summarized in Table 1.

Table 1. Number of sample plots classified into white birch (Bw) and trembling aspen $(\mathrm{Pt})$ residual stand types by administrative region. $(P=$ pure; $\mathbf{D}=$ dominant; $L=$ leading $]$

\begin{tabular}{lcccccccc}
\hline & \multicolumn{4}{c}{ Birch } & \multicolumn{4}{c}{ Aspen } \\
\cline { 2 - 9 } Region & BwP & BwD & BwL & Total & PtP & PtD & PtL & Total \\
\hline Northeast & 34 & 12 & 3 & 49 & 171 & 25 & 5 & 201 \\
Northwest & 79 & 13 & 3 & 95 & 107 & 27 & 4 & 138 \\
\hline Total & $\mathbf{1 1 3}$ & $\mathbf{2 5}$ & $\mathbf{6}$ & $\mathbf{1 4 4}$ & $\mathbf{2 7 8}$ & $\mathbf{5 2}$ & $\mathbf{9}$ & $\mathbf{3 3 9}$ \\
\hline
\end{tabular}

Because of the relatively small number of truly monospecific aspen and birch stands, the small sample size for some residual stand types, and the variation in number of plots of a given stand type in our 29 blocks, sample plots were grouped into those having either aspen (i.e., PtL, PtD, and PtP) or birch (i.e., BwL, BwD, and $\mathrm{BwP}$ ) as the primary tree species. Most $(\geq 78 \%)$ stands in each of these classes were classified as pure based on percent BA. In the combined aspen and birch stand classes, the living BA of aspen and birch averaged about $90.0 \%$ and $89.7 \%$, respectively. Because the climate in northwestern Ontario is comparatively drier (Crins et al. 2009), all plots were classified by provincial administrative region, i.e., northeast or northwest, for use as a random factor in nonlinear mixed effects modelling (described below).

For each stand class, standard curve fitting procedures were used to examine the relationships between GSF and stand features. The corrected Akaike's information criterion (AICc) and the NLIN procedure of SAS (SAS Institute Inc., Cary NC) were used to determine the effect of including dead stems to derive predictive models. Using a two-parameter negative exponential model, including both living and dead stems, resulted in AICc ranging from 27 to 64 and 11 to 14 for the aspen and birch stand classes, respectively, as compared with models developed using living stems. Therefore, all further model evaluations of stand structural features were performed using plot data for living stems only. These findings are consistent with previous results indicating that estimates of canopy transmittance using hemispherical photographs are influenced primarily by foliage in the tree canopy, with only a weak dependence on stem and branch biomass (Fournier et al. 1996).

To identify a model that best fit the relationship between GSF and stand BA, N, and SDI, four linear and nonlinear models were explored (Table 2). Models (1) and (2) were linearized to avoid convergence problems sometimes encountered when using the NLIN procedure of SAS. Models (3) and (4) provided a comparatively superior fit to the data. However, for model (3) the coefficient of the inverse term $(1 / \mathrm{X})$ was highly insignificant $(p>0.45)$ for aspen and marginally significant $(0.03<\mathrm{p}<0.5)$ for birch for BA and SDI. This analysis and coefficients of determination $\left(\mathrm{R}^{2}\right)$ values indicated that the single, two-parameter negative exponential model (model 4) provided the best fit to the data. This model is analogous to the Beer-Lambert law that describes average theoretical light transmittance through homogenous forest canopies, with $\mathrm{X}$ acting as a proxy for leaf area index and $\mathrm{a}_{1}$ as an extinction coefficient that quantifies attenuation of light as a function of the spatial arrangement of foliage in the canopy (Lieffers et al. 1999).

This model was fit to both stand classes using the nlme mixed effects nonlinear modelling package of $\mathrm{R}$ (Pinheiro et al. 2011). Random effects were added sequentially to the fixed effects regression parameters $a_{0}$ and $a_{1}$ (i.e., $a_{0}, a_{1}, a_{0}+a_{1}$ ). Random effects $\left(\sigma_{\mathrm{s}}\right)$ associated with region, block, and block nested in location were not significant for any coefficient or independent variable for either stand class. Location level random effects for $\mathrm{a}_{0}$ were sometimes significant. Models with random effects were further evaluated by assessing model residuals and two goodness-of-fit criteria: the negative log-likelihood ratio, -ln (L), and Akaike's information criterion (AIC). The model with the smallest - $\ln (\mathrm{L})$ and AIC val- 
Table 2. Results of initial evaluation of the relationships of stand basal area (BA], stand density (N), and stand density index (SDI) with the global site factor for white birch (a) and trembling aspen (b). Original nonlinear and fitted linear models and coefficients of determination $\left(R^{2}\right]$ are presented.

\begin{tabular}{|c|c|c|c|c|}
\hline \multirow[b]{2}{*}{ Original model } & \multirow[b]{2}{*}{ Fitted model } & \multicolumn{3}{|c|}{$\mathbf{R}^{2}$} \\
\hline & & $\mathbf{X}=\mathbf{B A}$ & $\mathbf{X}=\mathbf{N}$ & $\mathrm{X}=\mathrm{SDI}$ \\
\hline \multicolumn{5}{|l|}{ Birch } \\
\hline (1) $\exp (Y)=a X^{b}$ & $\mathrm{Y}=\mathrm{a}_{0}+\mathrm{a}_{1} \ln (\mathrm{X})$ & 0.54 & 0.53 & 0.55 \\
\hline (2) $Y=a X^{b} c^{x}$ & $\ln (Y)=a_{0}+a_{1} \ln (X)+a_{2} X$ & 0.52 & 0.50 & 0.54 \\
\hline (3) $\mathrm{Y}=\mathrm{a}+\mathrm{b}(1 / \mathrm{X})+\mathrm{c} \mathrm{X}$ & $\mathrm{Y}=\mathrm{a}_{0}+\mathrm{a}_{1}(1 / \mathrm{X})+\mathrm{a}_{2} \mathrm{X}$ & 0.54 & 0.53 & 0.56 \\
\hline (4) $\mathrm{Y}=\mathrm{a} \exp (-\mathrm{b} X)$ & $\mathrm{Y}=\mathrm{a}_{0} \exp \left(-\mathrm{a}_{1} \mathrm{X}\right)$ & 0.57 & 0.53 & 0.58 \\
\hline \multicolumn{5}{|l|}{ Aspen } \\
\hline (1) $\exp (Y)=a X^{b}$ & $\mathrm{Y}=\mathrm{a}_{0}+\mathrm{a}_{1} \ln (\mathrm{X})$ & 0.57 & 0.66 & 0.61 \\
\hline (2) $Y=a X^{b} c^{x}$ & $\ln (Y)=a_{0}+a_{1} \ln (X)+a_{2} X$ & 0.60 & 0.62 & 0.65 \\
\hline (3) $\mathrm{Y}=\mathrm{a}+\mathrm{b}(1 / \mathrm{X})+\mathrm{c} \mathrm{X}$ & $\mathrm{Y}=\mathrm{a}_{0}+\mathrm{a}_{1}(1 / \mathrm{X})+\mathrm{a}_{2} \mathrm{X}$ & 0.66 & 0.65 & 0.70 \\
\hline (4) $\mathrm{Y}=\mathrm{a} \exp (-\mathrm{b} \mathrm{X})$ & $\mathrm{Y}=\mathrm{a}_{0} \exp \left(-\mathrm{a}_{1} \mathrm{X}\right)$ & 0.69 & 0.73 & 0.69 \\
\hline
\end{tabular}

ues was considered best. To examine possible autocorrelation in the data within a stand class, two autocorrelation structures, first-order autoregressive, $\mathrm{AR}(1)$, and autoregressive moving average (ARMA), were evaluated and that which gave the best fit (i.e., smaller AIC) and provided expected behaviour of residuals selected. The coefficients of the final models were determined using the REML (restricted maximum likelihood) method.

The existence of significant differences in the relationships of GSF with BA, N, and SDI between the aspen and birch stand classes was assessed using the extra sums of squares approach and a single, two parameter negative exponential model (Neter and Wasserman 1974).

Descriptive statistics and frequency distributions of stand structural variables for each stand class were examined using the UNIVARIATE procedure of SAS. A Shapiro-Wilk test indicated stand age, mean $\mathrm{DBH}, \mathrm{BA}, \mathrm{N}, \mathrm{SDI}$, and the percentage of total BA and $\mathrm{N}$ were not normally distributed for multiple-stemmed trees. Therefore, stand class differences in these variables were tested using nonparametric statistics, the NPAR1WAY procedure of SAS, and a Kruskal-Wallis test ( $p$ $<0.05)$. The GLM procedure of SAS, one-way analysis of variance, and a Tukey-Kramer mean separation test $(\mathrm{p}<0.05)$ were used to assess differences in dominant tree height between stand classes. Model residuals were examined to verify that the assumptions of homogeneity of variance and normality were met. In all analyses, individual plot values were used as primary data.

\section{Results}

Age and structure varied widely among the 29 blocks sampled across northern Ontario (Table 3). Stand age ranged from 53 to 146 years, with $90 \%$ of the blocks between 75 and 125 years old. Total BA and $\mathrm{N}$ ranged from 1.4 to $33.6 \mathrm{~m}^{2} \mathrm{ha}^{-1}$ and 27 to 818 trees ha $^{-1}$, respectively. The percentage of BA and $\mathrm{N}$ represented by living trees in a block averaged $81.0 \%$ and $91.0 \%$, respectively, and ranged from about 56 to $90 \%$. Mean DBH and dominant tree height of the 29 blocks ranged from 17.9 to $37.3 \mathrm{~cm}$ and 12.7 to $25.4 \mathrm{~m}$, respectively. Mean stand age and $\mathrm{N}$ did not differ significantly between stand classes, but
$\mathbf{R}^{2}$

aspen stands had larger residual canopy trees and higher BA and SDI (Table 4). Birch trees with multiple basal stems were common, accounting for $33.5 \%$ of measured stems, while multi-stemmed aspen were much less frequent at roughly $3.5 \%$ of measured stems. The mean total living $\mathrm{BA}$ and $\mathrm{N}$ and the mean percentage of $\mathrm{BA}$ and $\mathrm{N}$ occurring as multiple-stemmed individuals were significantly lower for the aspen than the birch stand class (Table 4).

Canopy transmittance, as estimated by GSF, exhibited a significant nonlinear decline with increasing $\mathrm{BA}, \mathrm{N}$, and SDI for the aspen and birch stand classes, with variation in GSF increasing at higher values of residual stand BA, N, and SDI (Fig. 2). For both stand classes, GSF declined to about $20 \%$ at the highest BA, N, and SDI sampled. Comparatively greater variation in GSF with stand structural features was evident in the birch stand class, as reflected in slightly higher mean square error (Table 5). The random effects associated with $\mathrm{a}_{0}$ resulted in the smallest AIC for both species. For birch, however, this was only significant for BA. Random effects associated with $a_{1}$ were not significant for either stand class for BA, N, or SDI (Table 5). Of the two autocorrelation structures examined, the $\mathrm{AR}(1)$ structure resulted in the smallest AIC for both species for all stand characteristics except SDI for birch. The autocorrelation in this case, however, was not significant. The full and reduced nonlinear regression models differed significantly $(\mathrm{p}<0.05)$ between stand classes for BA and SDI, but not N. For aspen stands, a comparatively greater GSF was associated with a given BA and SDI (Fig. 3).

\section{Discussion}

The intensity and heterogeneity of light transmitted through the tree canopy to the understory depends on the species composition of the stand; the number, size, age, and spatial distribution of canopy trees; and, to a lesser extent, site factors that may influence crown architecture (Lieffers et al. 1999; Vieilledent et al. 2010). In our study, significant negative exponential relationships of GSF with BA, N, and SDI were found for aspen- and birch-dominated residual stands. Nonlinear, proportional reduction in GSF with increasing BA, N, and/or SDI is consistent with previous field studies reporting the relationship of these and other stand structural features with understory light in young and mature stands dominated by white birch (Comeau and Heinemann 2003), trembling aspen (Comeau et al. 2006,) and other Betula and Populus species (Johanssen 1996; Wall et al. 2010).

The effects of stand composition on canopy light transmittance are expressed through species differences in crown architecture, which determines the amount and distribution of leaf area within the crown (Stadt et al. 2005; Beaudet et al. 2011). Significant differences in nonlinear models for BA and SDI between stand classes are likely largely due to differences in crown geometry and porosity of the primary residual canopy species (Vieilledent et al. 2010). For trees of a given 
Table 3. Location, block, estimated stand age, number of sample plots, mean total and live basal area (BA), density (N), stem diameter (DBH), and dominant tree height for 29 surveyed areas in the northeast (a) and northwest (b) administrative regions of Ontario. Block mean values for $\mathrm{BA}, \mathrm{N}, \mathrm{DBH}$, and height refer to living trees with height $\geq 3 \mathrm{~m}$ and $\mathrm{DBH} \geq 10 \mathrm{~cm}$ ). Blocks with asterisks are unmanaged stands.

\begin{tabular}{|c|c|c|c|c|c|c|c|c|c|}
\hline \multirow[b]{2}{*}{ Location } & \multirow[b]{2}{*}{ Block } & \multirow{2}{*}{$\begin{array}{l}\text { Plot } \\
\text { (n) }\end{array}$} & \multirow{2}{*}{$\begin{array}{l}\text { Age } \\
(\mathrm{yr})\end{array}$} & Total BA & Live BA & Total N & Live $\mathbf{N}$ & \multirow{2}{*}{$\begin{array}{c}\text { DBH } \\
(\mathrm{cm})\end{array}$} & \multirow{2}{*}{$\begin{array}{l}\text { Height } \\
\quad(\mathrm{m})\end{array}$} \\
\hline & & & & \multicolumn{2}{|c|}{$\left(\mathrm{m}^{2} \mathrm{ha}^{-1}\right)$} & \multicolumn{2}{|c|}{$\left(\right.$ trees ha $\left.\mathbf{h}^{-1}\right)$} & & \\
\hline \multicolumn{10}{|l|}{ (a) Northeast } \\
\hline \multirow[t]{3}{*}{ Gogama } & 1 & 2 & 75 & 2.12 & 1.74 & 65 & 49 & 21.1 & 16.0 \\
\hline & $2^{\star}$ & 13 & 60 & 33.56 & 28.97 & 818 & 610 & 24.1 & 23.3 \\
\hline & 3 & 3 & 91 & 1.44 & 0.81 & 27 & 16 & 25.0 & 19.5 \\
\hline \multirow[t]{2}{*}{ Hearst } & 1 & 20 & $53-74$ & 6.10 & 5.29 & 113 & 95 & 26.1 & 19.0 \\
\hline & 2 & 16 & $104-114$ & 3.98 & 2.60 & 74.1 & 49 & 25.9 & 23.3 \\
\hline \multirow[t]{2}{*}{ Hornepayne } & 1 & 59 & $97-137$ & 26.07 & 18.94 & 275 & 195 & 34.1 & 25.4 \\
\hline & 2 & 58 & $95-109$ & 24.48 & 21.95 & 558 & 467 & 24.8 & 22.4 \\
\hline \multirow[t]{2}{*}{ Sault Ste. Marie } & 1 & 2 & 103 & 6.32 & 4.68 & 143 & 122 & 20.2 & 12.7 \\
\hline & 2 & 10 & 82 & 14.78 & 12.83 & 491 & 432 & 18.4 & 17.7 \\
\hline Temagami & 1 & 6 & 79 & 3.55 & 2.54 & 106 & 70 & 20.8 & 16.4 \\
\hline \multirow[t]{2}{*}{ Timmins } & 1 & 22 & 99 & 25.73 & 23.08 & 492 & 443 & 23.8 & 20.3 \\
\hline & 2 & 34 & 88 & 6.82 & 5.70 & 245 & 195 & 17.9 & 17.3 \\
\hline White River & $1^{*}$ & 5 & 70 & 33.23 & 28.76 & 598 & 474 & 27.4 & 25.2 \\
\hline \multicolumn{10}{|l|}{ (b) Northwest } \\
\hline \multirow{2}{*}{ Atikokan } & 1 & 27 & 88 & 14.80 & 12.76 & 318 & 250 & 25.8 & 21.4 \\
\hline & 2 & 11 & 79 & 7.19 & 5.48 & 222 & 185 & 18.4 & 15.3 \\
\hline \multirow[t]{4}{*}{ Geraldton } & 1 & 4 & 131 & 29.18 & 23.06 & 463 & 337 & 28.3 & 22.1 \\
\hline & 2 & 10 & 131 & 5.49 & 4.88 & 57 & 50 & 36.4 & 23.1 \\
\hline & 3 & 12 & 121 & 23.95 & 20.53 & 506 & 382 & 26.2 & 22.5 \\
\hline & 4 & 10 & 146 & 17.38 & 15.55 & 146 & 123 & 37.3 & 24.4 \\
\hline \multirow[t]{5}{*}{ Ignace } & 1 & 13 & 87 & 8.66 & 7.15 & 219 & 176 & 22.7 & 18.0 \\
\hline & 2 & 28 & 117 & 9.44 & 8.47 & 178 & 159 & 24.9 & 18.7 \\
\hline & 3 & 14 & 94 & 15.61 & 11.14 & 333 & 197 & 27.5 & 22.7 \\
\hline & $4^{*}$ & 10 & 68 & 32.18 & 25.7 & 776 & 525 & 24.2 & 24.4 \\
\hline & 5 & 15 & 88 & 6.19 & 5.39 & 91 & 74 & 28.5 & 22.5 \\
\hline \multirow[t]{3}{*}{ Sioux Lookout } & 1 & 8 & 97 & 3.99 & 2.95 & 108 & 83 & 20.5 & 17.4 \\
\hline & 2 & 8 & $89-119$ & 8.57 & 7.27 & 91 & 67 & 34.7 & 23.5 \\
\hline & 3 & 43 & $89-99$ & 11.79 & 10.43 & 430 & 378 & 18.3 & 16.0 \\
\hline \multirow[t]{2}{*}{ Thunder Bay } & 1 & 3 & 87 & 12.17 & 8.70 & 276 & 195 & 23.2 & 21.8 \\
\hline & 2 & 17 & 88 & 6.36 & 5.06 & 202 & 178 & 18.5 & 14.1 \\
\hline
\end{tabular}

$\mathrm{DBH}$ or height, birch has a larger crown radius, crown depth, and leaf biomass than aspen (Lambert et al. 2005; Stadt et al. 2005; Beaudet et al. 2011). Birch also has a higher average leaf area density (i.e., leaf area per unit crown volume) (Stadt et al. 2005) and a lower crown porosity (Beaudet et al. 2011). Therefore, for a given tree size, birch crowns support higher total leaf area and transmit less light than the smaller, more open crowns of aspen. Therefore, when stand structure is expressed as a function of DBH (i.e., BA and SDI), and given species difference in crown architecture, it is not unexpected that birch stands of a given BA and SDI exhibit lower estimated GSF than do aspen stands. Lower understory light lev- els for birch- than for aspen-dominated stands were reported in the interior cedar hemlock forest zone of British Columbia (Canham et al. 1999).

Lack of differences in the relationship of GSF and N between stand classes likely results from the smaller mean stem $\mathrm{DBH}$ and height of birch relative to aspen in the residual stands sampled. Using allometric equations that estimate crown geometry from stem size for boreal mixedwoods of eastern Canada (Stadt et al. 2005; Beaudet et al. 2011), and the mean $\mathrm{DBH}$ and height of aspen and birch stands in our study (Table 4), the predicted crown length of aspen and birch stands differ by $<3 \%$. Also, the estimated radius of the more 
Table 4. Mean stand age, stem diameter (DBH), dominant tree height, basal area (BA), density (N), stand density index (SDI), and the percent basal area $\left[B A_{m}\right.$ ] and density $\left(\mathrm{N}_{\mathrm{m}}\right.$ ) of multiple stemmed canopy trees for the white birch and trembling aspen stand classes. Means followed by the same letter do not differ significantly $(\mathrm{p}<0.05)$.

\begin{tabular}{lcccccccc}
\hline Stand class & $\begin{array}{c}\text { Age } \\
(\mathbf{y r})\end{array}$ & $\begin{array}{c}\mathbf{D B H} \\
(\mathbf{c m})\end{array}$ & $\begin{array}{c}\text { Height } \\
(\mathbf{m})\end{array}$ & $\begin{array}{c}\mathbf{B A} \\
\left(\mathbf{m}^{\mathbf{2}} \mathbf{h a}^{-\mathbf{1}}\right)\end{array}$ & $\begin{array}{c}\mathbf{N} \\
\left(\mathbf{t r e e s ~ h a}^{-1}\right)\end{array}$ & $\mathbf{S D I}$ & $\begin{array}{c}\mathbf{B A}_{\mathbf{m}} \\
\mathbf{( \% )}\end{array}$ & $\begin{array}{c}\mathbf{N}_{\mathbf{m}} \\
(\mathbf{\%})\end{array}$ \\
\hline Birch & $95 \mathrm{a}$ & $19.9 \mathrm{~b}$ & $16.6 \mathrm{~b}$ & $7.2 \mathrm{~b}$ & $236 \mathrm{a}$ & $160 \mathrm{~b}$ & $24.0 \mathrm{a}$ & $25.3 \mathrm{a}$ \\
Aspen & $97 \mathrm{a}$ & $27.4 \mathrm{a}$ & $22.0 \mathrm{a}$ & $15.6 \mathrm{a}$ & $273 \mathrm{a}$ & $304 \mathrm{a}$ & $3.4 \mathrm{~b}$ & $4.4 \mathrm{~b}$ \\
\hline
\end{tabular}
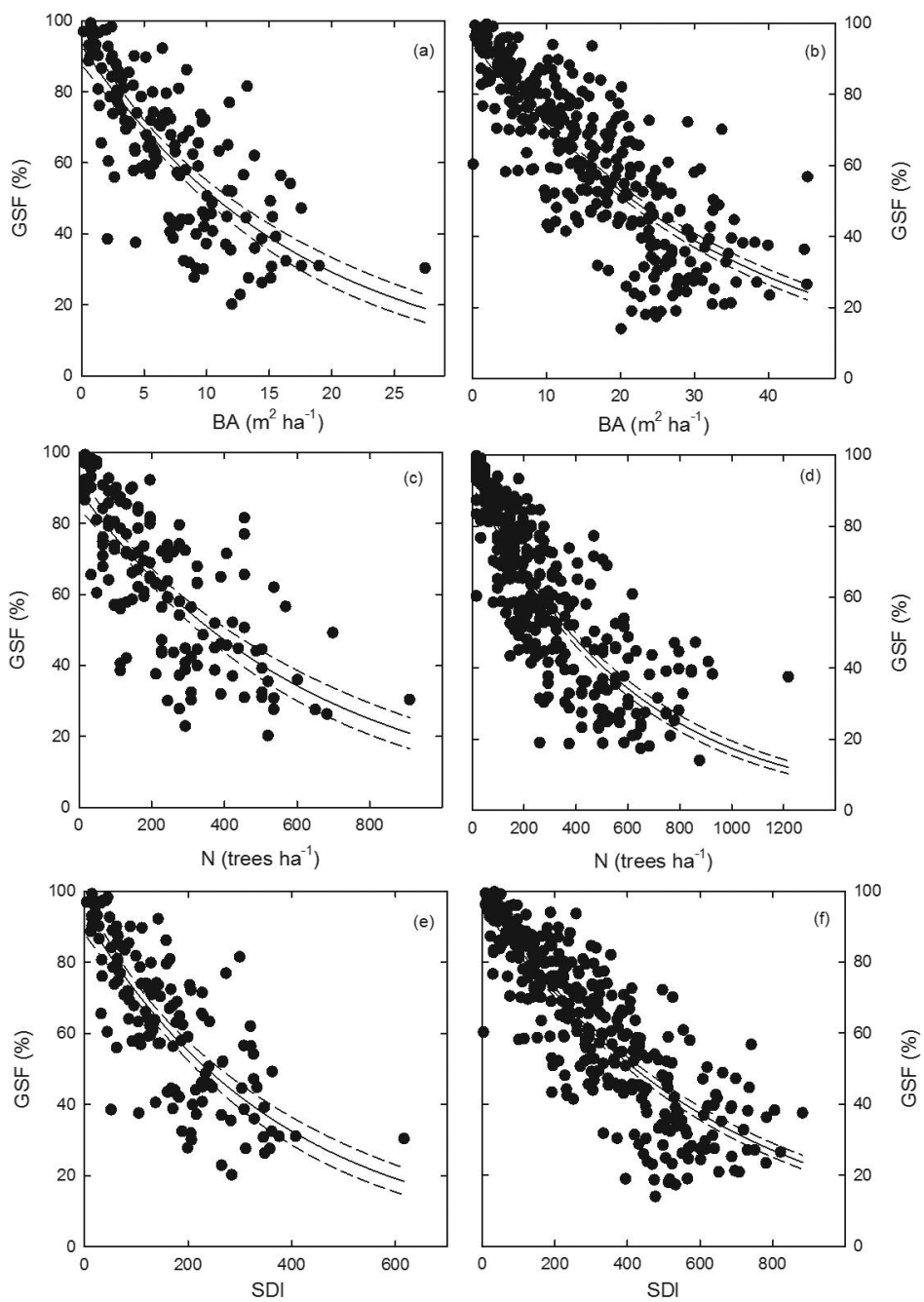

Fig. 2. Relationship of global site factor (GSF) with basal area (a,b), density (c,d), and

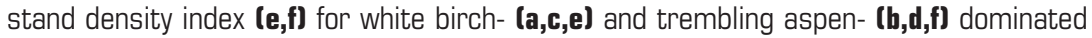
stands. Nonlinear regression line (solid line) and 95\% confidence intervals (dashed lines) are presented.

porous crowns of aspen was about 14\% larger than for birch. It therefore seems likely that, when stand structure was expressed as a function of $\mathrm{N}$, our nonlinear models for aspen and birch did not differ due to the similarity in estimated crown geometry after species differences in tree size are accounted for.
The initial harvesting of our study stands was centred on removing conifer and larger, more valuable hardwood stems. Therefore, the species, BA, N, size, and spatial distribution of residual canopy trees in our sample stands and plots was determined primarily by the number and location of marketable stems available for harvesting, with a slight secondary effect of regional differences in harvesting methods and machinery used that can influence residual spatial pattern (David et al. 2001). As a result, our stands and plots were characterized by a mosaic of aggregated patches of trees, small canopy gaps, and scattered individual trees of various sizes, many of which were mixtures of aspen, birch, and other species. The best fit nonlinear models defining the relationship of GSF with $\mathrm{BA}, \mathrm{N}$, and SDI explained 73 and $55 \%$ of the variation for aspen and birch stand classes, respectively (Table 2). Part of this comparatively high variability may be associated with our models being derived for residual stands dominated by aspen or birch, rather than monospecific stands of these species (Perot et al. 2017). Spatial variation in tree distribution was not assessed in our study, but it is likely that the irregular pattern of residual canopy trees also contributed to the relatively high variability in GSF with stand structural features (Battaglia et al. 2002; Ligot et al. 2016). Moreover, this source of variation was likely greater in the birch-dominated residual stands, in part because a significant proportion of birch trees had clumped, multiple stems (Comeau and Heineman 2003). Birch exhibits prolific basal stem sprouting following wildfire and harvesting, with stumps supporting from 2 to 15 stems (Perala and Alm 1990). In our study, birch stands were characterized by both scattered singlestemmed trees and small patches of multiple-stemmed clumps, with about one third of all stems and $25 \%$ of BA and $\mathrm{N}$ arising from stump sprouts. By comparison, aspen naturally regenerates primarily by root suckering and rarely exhibits basal stem sprouting (Perala and Alm 1990), and few multi-stemmed aspen trees were observed in our study.

Stand structural features most strongly correlated with total canopy leaf area have the largest relative influence on canopy transmittance (Lieffers et al. 1999). In this assessment of stand structural determinants of canopy transmittance, we 
Table 5. Nonlinear mixed effects model regression parameter estimates, standard error (SE), variance of random error $\left(\boldsymbol{\sigma}_{\mathrm{e}}{ }^{2}\right.$ ), variance of random location effects $\left(\sigma_{\mathrm{s}}{ }^{2}\right)$, autocorrelation $(\rho)$, the negative log-likelihood $[-\ln (L)]$, and Akaike's Information Criterion (AIC) for the 2 parameter negative exponential equation (4) describing the relationship of global site factor (GSF) with basal area (BA), density (N), and stand density index (SDI) for the white birch (a) and trembling aspen (b) stand classes. ${ }^{\text {b }}$

\begin{tabular}{|c|c|c|c|c|c|c|}
\hline \multirow[b]{2}{*}{ Parameters } & \multicolumn{2}{|c|}{ BA } & \multicolumn{2}{|c|}{$\mathbf{N}$} & \multicolumn{2}{|c|}{ SDI } \\
\hline & Estimate & SE & Estimate & SE & Estimate & SE \\
\hline \multicolumn{7}{|l|}{ a. Birch } \\
\hline $\mathrm{a}_{0}$ & 91.0834 & 3.1990 & 89.0535 & 2.8587 & 93.3643 & 2.6767 \\
\hline$a_{1}$ & 0.0524 & 0.0048 & 0.0015 & 0.0001 & 0.0026 & 0.0002 \\
\hline$\sigma_{\mathrm{e}}^{2}$ & 176.97 & - & 202.64 & - & 179.37 & - \\
\hline$\sigma_{s}^{2}$ & 20.31 & - & - & - & - & - \\
\hline$\rho^{s}$ & 0.1201 & - & 0.1504 & - & - & - \\
\hline$-\ln (\mathrm{L})$ & 580.85 & - & 584.11 & - & 576.96 & - \\
\hline AIC & 1171.70 & - & 1176.21 & - & 1159.92 & - \\
\hline \multicolumn{7}{|l|}{ b. Aspen } \\
\hline $\mathrm{a}_{0}$ & 95.6727 & 2.6367 & 90.5476 & 2.4024 & 96.9627 & 2.2327 \\
\hline$a_{1}$ & 0.0311 & 0.0014 & 0.0015 & 0.0001 & 0.0016 & 0.0001 \\
\hline$\sigma_{\mathrm{e}}^{2}$ & 141.51 & - & 147.28 & - & 125.80 & - \\
\hline$\sigma_{s}^{2}$ & 36.76 & - & 28.84 & - & 19.99 & - \\
\hline$\rho$ & 0.2020 & - & 0.2789 & - & 0.2405 & - \\
\hline$-\ln (\mathrm{L})$ & 1322.56 & - & 1324.95 & - & 1301.16 & - \\
\hline AIC & 2655.11 & - & 2659.90 & - & 2612.31 & - \\
\hline
\end{tabular}

${ }^{\mathrm{a}} \mathrm{GSF}=\mathrm{a}_{0} \exp ^{\left(-\mathrm{a} 1^{*} \mathrm{X}\right)}$

bonsignificant $\sigma_{\mathrm{s}}^{2}$ are not presented.

focused on the influence of residual BA, N, and SDI in recently harvested boreal mixedwood stands spread across northern Ontario. As they influence total stand leaf area and crown architecture, stand age and site factors can have significant but relatively minor effects on canopy transmittance (Vieilledent et al. 2010). Our reliance on stands created by operational harvesting of economically mature boreal mixedwood stands precluded a rigorous examination of the effects of these two factors on the relationship of canopy transmittance. However, our nonlinear mixed modelling approach did not detect strong random effects, and therefore potential variation in site factors, among our study blocks. Further, a small number (i.e., $\leq 2$ ) of subordinate trees $<10 \mathrm{~cm} \mathrm{DBH}$ and $<3$ $\mathrm{m}$ in height not classified as suitable residual trees were removed from some of our plots (OMNR 2010). As a result, the GSF values of these plots may slightly overestimate actual post-harvesting canopy transmittance. Importantly, our models do not account for any additional light attenuation due to understory vegetation that could influence the performance of crop tree regeneration $<1 \mathrm{~m}$ tall. Therefore, our models are broadly suited for estimating average initial canopy transmittance of aspen- and birch-dominated residual stands created by harvesting of boreal mixedwood stands of northern Ontario centred on canopy tree retention of hardwood stems with low commercial value. Finally, for both stand classes BA and SDI are better predictors of canopy transmittance than $\mathrm{N}$ because of the strong allometric relationship of DBH with crown features associated with light interception. However, our N-based models have practical value in general field assessment of canopy transmittance, despite the absence of a direct functional relationship between stand density and crown geometry.

\section{Conclusions and Application}

Despite its limitations, and in the absence of more complex light models that can be applied with available forest inventory data, our study provides simple models as practical tools that are useful in guiding the selection of appropriate silvicultural systems to attain a desired future forest condition when managing boreal mixedwoods (OMNRF 2015). Where the number of retained trees is expected to be higher than the minimum required, the silvicultural objectives of the site must be consistent with the structure and composition of a residual stand, and based on the probability of successful regeneration of desired species under the light conditions created by the residual canopy, as articulated in provincial silviculture guidelines (OMNRF 2015). In these cases, our models can be used to estimate the approximate range in $\mathrm{BA}, \mathrm{N}$, and SDI of aspen- and birch-dominated residual stands associated with application of the clearcut, shelterwood, or selection systems in boreal mixedwoods (Table 6). Our models can also guide regeneration planning through their use to estimate target residual $\mathrm{BA}, \mathrm{N}$, and SDI associated with light levels linked to successful regeneration of boreal mixedwood tree species (Lieffers et al. 1999). For example, underplanting white spruce beneath partial aspen canopies has been suggested to have many potential economic and ecological benefits relative to even-aged management of plantations (Kabzems et al. 2016), including adaptation to climate change (Park et al. 2014). Our models estimate that, in the absence of overtopping woody understory vegetation, aspen canopies with BA of about $28 \mathrm{~m}^{2} \mathrm{ha}^{-1}$, N of 545 trees ha ${ }^{-1}$, and SDI of 553 would create the $40 \%$ understory light levels associated with maximum height growth rate of underplanted white spruce seedlings (Lieffers and Stadt 1994).- 

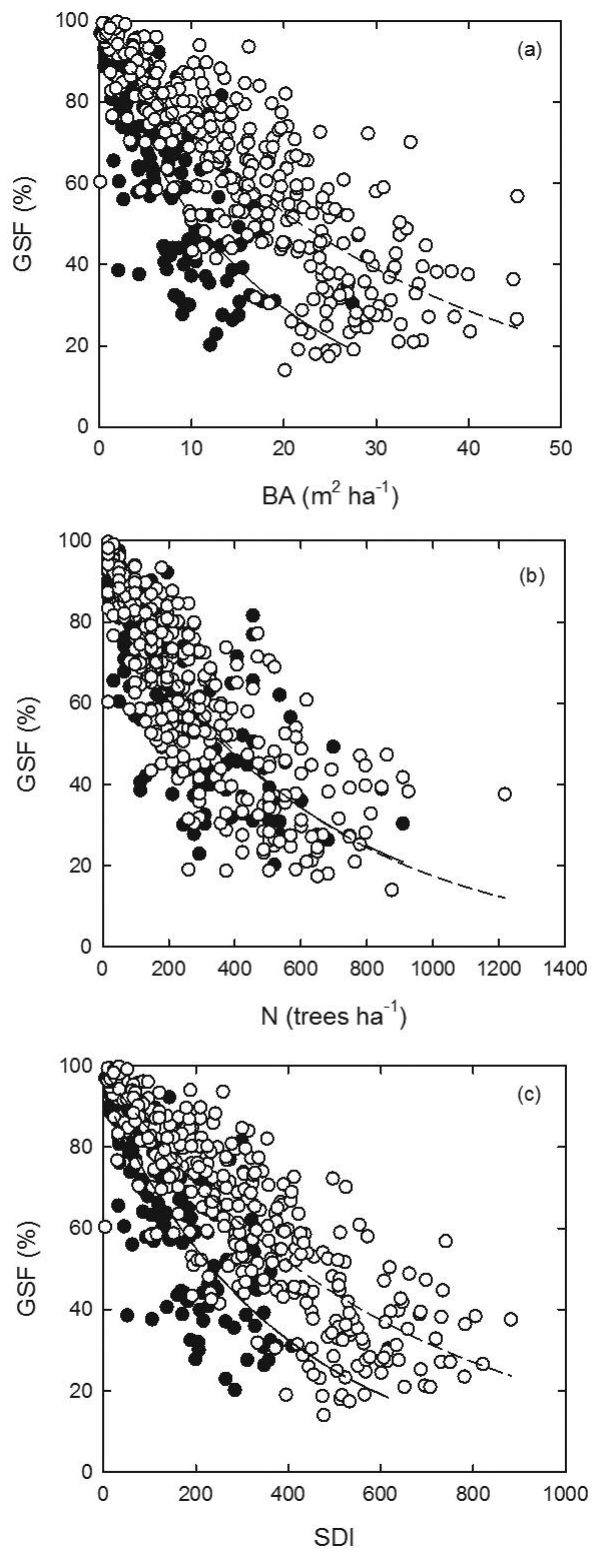

Fig. 3. Comparative relationships of global site factor (GSF) with basal area (BA) (a), density (N) (b), and stand density index (SDI) (c) for white birch- (solid circles, solid line) and trembling aspendominated (open circles, dashed line) stand classes. Nonlinear regression lines are presented.

An ecosystem management model for boreal mixedwoods based on the natural ecosystem dynamics of this region has been proposed to balance fibre production with biodiversity conservation and ecological function (Bergeron and Harvey 1997; Harvey et al. 2002). This model advocates the use of a variety of site- and stand-specific silviculture practices to emulate natural ecosystem dynamics through the purposeful modification of stand structure, composition, and developmental processes to create a managed landscape representative of the pre-industrial forest of the region (Bergeron and Harvey 1997; Harvey et al. 2002). Reduced use of clearcutting
Table 6. Mean values for residual stand basal area (BA; $\mathrm{m}^{2}$ ha- ${ }^{-}$), density ( $\mathrm{N}$; stems $\mathrm{ha}^{-1}$ ), and stand density index (SDI) at $70 \%$ (a) and $30 \%$ (b) understory light for the white birch and aspen stand class.

\begin{tabular}{lcc}
\hline Stand class & Stand feature & Mean \\
\hline (a) & & \\
Birch & BA & 5.0 \\
& N & 161 \\
& SDI & 111 \\
Aspen & BA & 10.1 \\
& N & 172 \\
(b) & SDI & 204 \\
Birch & & \\
& BA & 21.2 \\
& N & 725 \\
Aspen & SDI & 437 \\
& BA & 37.3 \\
& N & 737 \\
& SDI & 733 \\
\hline
\end{tabular}

and increased canopy retention are important components of this approach. For example, partial harvesting of the initial cohort of hardwood species is identified as a method to create managed analogues of older stand developmental stages (Brais et al. 2013; Man et al. 2013; Prévost and DeBlois 2014) that are underrepresented in comparatively humid regions of eastern Canada with relatively long fire cycles where reliance on even-aged management can truncate the natural age class distribution (Cyr et al. 2010; Venier et al. 2014). Silvicultural practices that retain a portion of the canopy to restore and maintain structural complexity and compositional diversity are also increasingly recognized as valid approaches to conserve biodiversity (Rosenvald and Lõhmus 2008; Fredrowitz et al. 2014); maintain ecosystem services, function, and resilience under current conditions (Franklin et al. 1997; Lindenmayer et al. 2012); and adapt forests to climate change and future disturbance regimes (Mori and Kitagawa 2014; Park et al. 2014). Given these findings, viewing higher than minimum required residual stand density in a strict economic sense as a wasteful practice, despite the lack of markets for many of these stems, ignores the potential value of increased tree retention as a component of ecosystem management and climate change adaptation, provided it is not associated with removing only the large, high quality stems (high grading). While the absence of commercial markets for hardwood fibre clearly complicates even-aged management of boreal mixedwoods, it also provides an incentive for increased testing and use of a natural dynamics-based approach (Guay-Picard et al. 2015) to create a diverse (Cavard et al. 2011), productive (Zhang et al. 2012), and resilient (Drever et al. 2006) forest through the deliberate retention of canopy trees regardless of their economic value.

\section{Acknowledgements}

We thank Ildiko Apavaloe, Dennis Bonner, Charlotte Bourdignon, Brad Bowen, Don Buck (deceased), Margaret Carruthers, John Coady, Veronique Falardeau, Don Farintosh, Bonny Fournier, Jack Harrison, Norm Iles (deceased), Herb Neubrand, Rick Sarmineto, Daryl Sebesta, Derrick 
Tirschmann, and Michael Young for help identifying potential study areas, Chris Ransom for providing Ontario forest management data, Tom Harris for discussions on industrial use of boreal hardwoods, and Brian Brown and Steve Billingsley for technical assistance. The thoughtful comments of Mike Brienesse, Neil Graham, Gordon Kayahara, and three anonymous reviewers improved the quality of this report. Thanks to Lisa Buse for editorial assistance and Trudy Vaittinen for help with graphics. This project was inspired by the selfless Christmas wish of Joe Churcher, OMNRF Crown Forest and Lands Policy Branch, who gracefully waited years to receive his gift.

\section{References}

Balatinecz, J.J., P. Mertens, L. De Boever, H. Yukun, J. Jin and J. van Acker. 2014. Properties, processing and utilization. In: J.G. Isebrands and J. Richardson (eds.). Poplars and Willows: Trees for Society and the Environment. pp. 527-561. CABI, Oxfordshire, UK. Battaglia, M.A., P. Mou, B. Palik and R.J. Mitchell. 2002. The effect of spatially variable overstory on the understory light environment of an open-canopied longleaf pine forest. Can. J. For. Res. 32: 1984-1991. doi:10:1139/X02-087

Beaudet, M., B.D. Harvey, C. Messier, K.D. Coates, J. Poulin, D.D. Kneeshaw, S. Brais and Y. Bergeron. 2011. Managing understory light conditions in boreal mixedwoods through variation in the intensity and spatial pattern of harvest: A modelling approach. For. Ecol. Manage. 261: 84-94. doi:10.1016/j.foreco.2010.09.033

Bergeron, Y, and B. Harvey. 1997. Basing silviculture on natural ecosystem dynamics: An approach applied to the southern boreal mixedwood forest of Quebec. For. Ecol. Manage. 92: 235-242. doi:10.1016/S0378-1127(96)03924-2

Brais, S., T.T. Work, É. Robert, C.D. O'Connor, M. Strukelj, A. Bose, D. Celentano and B.D. Harvey. 2013. Ecosystem responses to partial harvesting in eastern boreal mixedwood stands. Forests 4: 364-385. doi:10.3390/f4020364

Canham, C.D., K.D. Coates, P. Bartemucci and S. Quaglia. 1999. Measurement and modeling of spatially explicit variation in light transmission through interior cedar-hemlock forests of British Columbia. Can. J. For. Res. 29: 1775-1783. doi:10.1139X99-151

Cavard, X., S.E. MacDonald, Y. Bergeron and H.Y.H. Chen. 2011. Importance of mixedwoods for biodiversity conservation: Evidence for understory plants, songbirds, soil fauna, and ectomycorrhizae in northern forests. Environ. Rev. 19: 142-161. doi:10.1139/A11-004

Chen, H.Y.H. and R.V. Popadiuk. 2003. Dynamics of North American boreal mixedwoods. Environ. Rev. 10: 137-166. doi:10.1139/A02-007

Comeau, P.G. and J.L. Heineman. 2003. Predicting understory light microclimate from stand parameters in young paper birch (Betula papyrifera Marsh.) stands. For. Ecol. Manage. 180: 303-315. doi:10.1016/S0378-1127(02)00581-9

Comeau, P., J. Heineman and T. Newsome. 2006. Evaluation of relationships between understory light and aspen basal area in the British Columbia central interior. For. Ecol. Manage. 226: 80-87. doi:10.1016/j.foreco.2005.12.060

Crins, W.J., P.A. Gray, P.W.C. Uhlig and M. Wester. 2009. The ecosystems of Ontario. Part 1. Ecozones and Ecoregions. Ont. Min. Nat. Resour., Sci. Inf. Br., Inv. Monitor. Assess. Sec., Peterborough, ON. Tech. Rep. SIB TER IMA TR-01. 71 p.

Cyr, D., S. Gauthier, D.A. Etheridge, G.J. Kayahara and Y. Bergeron. 2010. A simple Bayesian Belief network for estimating the proportion of old-growth forest stands in the Clay Belt of Ontario using the provincial forest inventory. Can. J. For. Res. 40: 573-584. doi:10:1139/X10-025

David, A.J., J.C. Zasada, D.W. Gilmore and S.M. Landhäusser 2001. Current trends in the management of aspen and mixed aspen forests for sustainable production. Forest. Chron. 77: 525-532. doi:10.5558/tfc77525-3
Drever, C.R., G. Peterson, C. Messier, Y. Bergeron and M. Flannigan. 2006. Can forest management based on natural disturbances maintain ecological resilience? Can. J. For. Res. 36: 2285-2299. doi:10.1139/X06-132

Duchesne, I. and V. Rancourt. 2005. Towards an increased and optimized 1 ilization of white birch across Canada-Literature review and 1 commendations for future research. Forintek Canada Corp., Queb :c City, QC. Value to Wood No. FCC 28.

Fedrowitz, K. et al. 2014. Can retention forestry help conserve biodiversity? A meta-analysis. J. Appl. Ecol. 51: 1669-1679. doi:10.1111/1365-2664.12289

Fournier, R.A., R. Landry, N.M. August, G. Fedosejevs and R.P. Gauthier. 1996. Modelling light obstruction in three conifer forests using hemispherical photography and fine tree architecture. Agric. For. Meteorol. 82: 47-72. doi:10.1016/0168-1923(96)02345-3

Franklin, J.F., D.E. Berg, D.A Thornburgh and J.C. Tappeiner. 1997. Alternative silvicultural approaches to timber harvest: Variable retention harvest systems. In: Kohm, K.A. and J.F. Franklin (eds.). Creating a Forestry for the $21^{\text {st }}$ Century: The Science of Ecosystem Management. pp. 111-139. Island Press, Covelo, CA.

Gendron, F., C. Messier, E. Lo and P.G. Comeau. 2006. The angular distribution of diffuse photosynthetically active radiation under different sky conditions in the open and within deciduous and conifer forest stands of Quebec and British Columbia, Canada. Ann. For. Sci. 63: 43-53. doi:10.1051/forest:2005096

Guay-Picard, A., D. Auty, A.D. Munson and A. Achim. 2015. Partial harvesting in boreal mixedwoods: A case for planned heterogeneity in industrial silvicultural prescriptions. For. Ecol. Manage. 358: 291-302. doi:10.1016/j.foreco.2015.09.005

Harvey, B., A. Leduc, S. Gauthier and Y. Bergeron. 2002. Standlandscape integration in natural disturbance-based management of the southern boreal forest. For. Ecol. Manage. 155: 369-385. doi:10.1016/S0378-1127(01)00573-4

Hunter Jr., M.L. 1999. Maintaining biodiversity in forest ecosystems. Cambridge University Press, Cambridge, UK.

Johansson, T. 1996. Estimation of canopy density and irradiance in 20- to 40-year-old birch stands (Betula pubescens Erh. and Betula pendula Roth). Trees 10: 223-230. doi:10.1007/BF02185673

Kabzems, R., P.G. Comeau, C.N. Filipescu, B. Rogers and A.F. Linnell Nemec. 2016. Creating boreal mixedwoods by planting spruce under aspen: Successful establishment in uncertain climates. Can. J. For. Res. 46: 1217-1223. doi:.org/10.1139/cjfr-2015-0440

Lambert, M.-C., C.H. Ung and F. Raulier. 2005. Canadian national tree aboveground biomass equations. Can. J. For. Res. 35: 1996-2018. doi:10.1139/X05-112

Lieffers, V.J. and K.J. Stadt. 1994. Growth of understory Picea glauca, Calamagrostis canadensis, and Epilobium angustifolium in relation to overstory light transmission. Can. J. For. Res. 29:1193-1198. doi:10.1139/X94-157

Lieffers, V.J., C. Messier, K.J. Stadt, F. Gendron and P.G. Comeau. 1999. Prediction and managing light in the understory of boreal forests. Can. J. For. Res. 29: 796-811. doi:10.1139/X98-165

Ligot, G., A. Ameztegui, B. Courbaud, L. Coll and D. Kneeshaw. 2016. Tree light capture and spatial availability of understory light increase with species mixing and tree size heterogeneity. Can. J. For. Res. 46: 968-977. doi:10.1139/cifr-2016-0061

Lindenmayer, D.B., et al. 2012. A major shift to the retention approach for forestry can help resolve some global sustainability issues. Conserv. Lett. 5: 421-431. doi:10.1111/j.1755-263X.2012.00257X MacDonald, G.B. 1995. The case for boreal mixedwood management: An Ontario perspective. Forest. Chron. 71: 725-734. doi:10.5558/tfc71725-6

MacLean, D.W. 1960. Some aspects of the aspen-birch-spruce-fir type in Ontario. Can. Dept. For., For. Res. Div., Ottawa, ON. Tech Note No. 94. 24 p.

Man, R., J.A. Rice and G.B. MacDonald. 2013. Performance of planted spruce and natural regeneration after pre- and post-harvest spraying with glyphosate and partial cutting on an Ontario (Canada) 
boreal mixedwood site. Forestry 86: 475-480. doi:10.1093/ forestry/cpt018

Mori, A.S. and R. Kitagawa. 2014. Retention forestry as a major paradigm for safeguarding forest biodiversity in productive landscapes: A global meta-analysis. Biol. Cons. 175: 65-73. doi:10.1016/j.biocon.2014.04.016

Neter, J. and W. Wasserman. 1974. Applied linear statis ical models. Richard D. Irwin, Inc., Homewood, IL.

OMNR. 2003. [Ontario Ministry of Natural Resources]. Silviculture guide to managing spruce, fir, birch and aspen mixedwoods in Ontario's boreal forest. Version 1.0. Ont. Min. Nat. Resour., Toronto, ON.

OMNR. 2007. [Ontario Ministry of Natural Resources]. Scaling manual. Ont. Min. Nat. Resour., Toronto, ON.

OMNR. 2010. [Ontario Ministry of Natural Resources]. Forest management guide for conserving biodiversity at the stand and site scales. Ont. Min. Nat. Resour., Toronto, ON.

OMNRF. 2015. [Ontario Ministry of Natural Resources and Forestry]. Forest management guide to silviculture in the Great Lakes-St. Lawrence and boreal forests of Ontario. Ont. Min. Nat. Resour. For., Toronto, ON.

Park, A., K. Puettmann, E. Wilson, C. Messier, S. Kames and A. Dhar. 2014. Can boreal and temperate forest management be adapted to the uncertainties of $21^{\text {st }}$ century climate change? Crit. Rev. Pl. Sci. 33: 251-285. doi:10.1080/07352689.2014.858956

Perala, D.A. and A.A. Alm. 1990. Regeneration silviculture of birch: A review. For. Ecol. Manage. 32: 39-77. doi:10.1016/03781127(90)90105-K

Perot, T., A. Mårell, N. Korboulewsky, V. Seigner and P. Balandier. 2017. Modeling and predicting solar radiation transmittance in mixed forests at a within-stand scale from tree species basal area. For. Ecol. Manage. 390:127-136. doi:10.1016/j.foreco.2017.01.023

Pierpoint, G. 1981. Site types of the boreal mixedwood forest. In: R.D. Whitney and K.M. McClain (eds.). Boreal Mixedwood Symposium, Thunder Bay, ON, 16-18 September 1980. pp. 10-16. Dept. Environ., Can. For. Serv., Gt. Lakes For. Ctr., Sault Ste. Marie, ON. COJFRC Symp. Proc. O-P-9.

Pinheiro, J.C., D.M. Bates, S. Debroy, D. Sarkar and R Core Team. 2011. nlme: Linear and nonlinear mixed effects models. R. Package version 3.1-102. http://CRAN.R-project.org/web/packages=nlme.

Prévost, M. and J. DeBlois. 2014. Shelterwood cutting to release coniferous advance growth and limit aspen sucker development in a boreal mixedwood stand. For. Ecol. Manage. 323: 148-157. doi:10.1016/j.foreco.2014.03.015
Reineke, L.H. 1933. Perfecting a stand density index for even-aged forests. J. Agric. Sci. 36: 627-639.

Robison, S.A. and B.C. McCarthy. 1999. Potential factors affecting the estimation of light availability using hemispherical photography in oak forest understories. J. Tott. Bot. Soc. 126(4): 344-349. doi: $10.2307 / 2997318$

Rosenvald, R. and A. Lõ ımus. 2008. For what, when, and where is green-tree retention br ter than clear-cutting? A review of the biodiversity aspects. For. Ecol. Manage. 255: 1-15. doi:10.1016/ j.foreco.2007.09.016

Rowe, J.S. 1972. Forest regions of Canada. Dept. Environ, Can. For. Serv., Ottawa, ON. Pub. No. 1300. 173 p.

Stadt, K.J., V.J. Lieffers, R.J. Hall and C. Messier. 2005. Spatially explicit modelling of PAR transmission and growth of Picea glauca and Abies balsamea in the boreal forests of Alberta and Quebec. Can. J. For. Res. 35: 1-12. doi:10.1139/X04-141

Taylor, R. 2009. Crisis in the wood products industry and markets: Perspectives from North America. Unasylva 233(60): 13-22.

Venier, L.A. et al. 2014. Effects on natural resource management on the terrestrial biodiversity of Canadian boreal forests. Environ. Rev. 22: 457-490. doi:10.1139/er-2013-0075

Vieilledent, G., B. Courbaud, G. Kunstler, J.-F. Dhôte and J.S. Clark. 2010. Individual variability in tree allometry determines light resource allocation in forest ecosystems: A hierarchical Bayesian approach. Oecologia 163: 759-773. doi:10.1007/s00442-010-1581-9 Wall, A.J., P.D. Kemp, A.D. Mackay and I.L. Power. 2010. Evaluation of easily measured stand inventory parameters as predictors of PAR transmittance for use in poplar silvopastoral management. Agric. Eco. Environ. 139: 665-674. doi:10.1016/j.agee.2010.10.012

Watkins, L. 2011. The forest resources of Ontario. Ont. Min. Nat. Resour., For. Eval. Std. Sect., For. Br., Sault Ste. Marie, ON. 307 p.

West, P.W. 2009. Tree and Forest Measurement, second edition. Springer-Verlag, Berlin, Germany.

Zhang, Y., H.Y.H. Chen and P.B. Reich. 2012. Forest productivity increases with evenness, species richness, and trait variation a global meta-analysis. J. Ecol. 100: 742-749. doi:10.1111/j.1365-2745.2011. 01944.X 